\title{
SHOULD THE FLAG FIT, OR MUST WE ACQUIT?
}

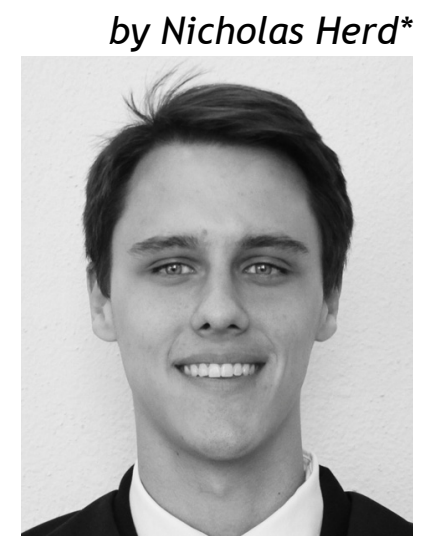

An analysis of Freedom of Expression in South Africa, with specific reference to Hate Speech and the old South African Flag.

I do not agree with what you have to say, but I'll defend to the death your right to say it. ${ }^{1}$

\section{Introduction}

Hate speech is a particular strain of expression that a society considers antithetical to its values and, through the law, seeks to curb its emission by way of regulation. As with all controversial issues within political discourse, hate speech prohibitions will either increase in scope and intensity through law reform, or recede by legislative repeal or intervention of a constitutional nature by the judiciary. ${ }^{2}$

* $\quad$ LLB III Student (University of Pretoria), Judge of the Constitutional Tribunal (2019) (University of Pretoria). I must express my appreciation of Marno Swart (a colleague on the Tribunal and dear friend) for his engagement and keen eye. I am exceedingly grateful for and indebted to Prof A. Kok (Associate Professor of Law, University of Pretoria) for his insights, patience and encouragement. I would also like to thank all of my close friends - in particular Abena Osei-Fofie and Duane van Wyk - for their support. Any impediments are attributable to me and me alone.

1 A quote attempting to capture the beliefs of the 18th century French philosopher Voltaire, and by that virtue, the Western conceptualisation of individual freedom of expression. See BE Hall The Friends of Voltaire (1906).

2 As is promised with the Prevention and Combating of Hate Crimes and Hate Speech Bill, B9-2018 http://www.justice.gov.za/legislation/hcbill/B9-2018HateCrimesBill.pdf (accessed 14 May 2019). See section 10 of the Promotion of Equality and Prevention of Unfair Discrimination Act 4 of 2000 (PEPUDA). 
When considering issues of freedom of expression from a constitutional law viewpoint at the very least, the egregious speech ought to be determined by its potential value in sparking necessary discourse, as well as its propensity to divide and harm a society still in the grip of the aftermath of apartheid. Ancillary and intimately connected to this is the question of content - where to draw the boundaries of hate speech. Which expression should we deem sufficiently egregious and harmful such that it has no place in our national and public conversation?

This paper is written in response to recent litigation before the Equality Court concerning the old South African flag. ${ }^{3}$ Following alleged gratuitous displays of the flag, the Nelson Mandela Foundation in February 2018 announced that it had made an application to the Equality Court for an order declaring the flag's gratuitous display as, inter alia, hate speech. ${ }^{4}$ The declaration sought would arguably make for a limitation on one's right to freedom of expression.

Accordingly, I assess the relief sought by the Nelson Mandela Foundation by evaluating: (1) whether conceptually hate speech prohibitions are legitimate; (2) whether section 10 of PEPUDA passes constitutional muster; and (3) whether the flag can be outright classified as hate speech under PEPUDA.

\section{A conceptual consideration of hate speech prohibitions}

\subsection{General points of departure}

It ought to be patent that hateful speech can cause harm to both intended targets and members of society alike. ${ }^{5}$ The Supreme Court of Canada, in the context of a hate speech prohibition and antiSemitic teachings, quite aptly summated the effects of hate speech

3 Reference made to 'a flag' or 'the flag' hereafter will be to the old South African flag unless indicated otherwise.

4 The application by the Foundation followed apparent displays of the flag in nationwide '\#BlackMonday' protests over attacks on farmers. The matter was set down before and heard by Deputy Judge President Phineas Mojapelo in the Equality Court on 29 and 30 April 2019. At the time of writing, Judgment remained reserved in the matter. See South African Human Rights Commission (SAHRC) 'Bid to ban old 'racist' SA flag' 26 February 2019 https://www. sahrc.org.za/index.php/sahrc-media/news/item/1780-bid-to-ban-old-racist-saflag (accessed 14 May 2019); C Ryan 'Here are the arguments for and against banning the old South African flag' 29 April 2019 https://www.groundup.org.za/ article/equality-court-asked-declare-old-sa-flag-hate-speech/ (accessed 11 May 2019); see section 10 of the PEPUDA.

5 D Milo, G Penfold \& A Stein 'Freedom of Expression' in S Woolman, T Roux, J Klaaren, A Stein, M Chaskalson \& M Bishop (eds) Constitutional Law of South Africa (2nd Edition, OS, April 2014) 15, 73. 
in observing that, the 'emotional damage' caused thereby may occasion 'grave psychological and social' harm in the form of humiliation and degradation. ${ }^{6}$ The Court remarked that the consequences of such expression bear heavily on a nation animated by values such as tolerance and dignity. ${ }^{7}$

The South African Constitutional Court in Islamic Unity Convention $v$ Independent Broadcasting Authority and Others (hereafter Islamic Unity) premised its analysis similarly, properly recognising the transformative nature of the Constitution, South Africa's history, and its commitment to 'dignity, equality, freedom, the healing of the divisions of the past and building a united South Africa'. ${ }^{8}$ The Court has gone further in keeping with a transformative and contextual approach. ${ }^{9}$ It remarked that unchecked hate speech striking at 'immutable characteristics' such as race are 'particularly harmful to the achievement of these [constitutional] values' and can 'reinforce patterns of discrimination' which has 'the potential to further divide society'. ${ }^{10}$

Hate speech further has the propensity to foster tension, division and fan the flames of violence, discrimination and other anti-social behaviour. ${ }^{11}$ Put bluntly, hate speech has the potential to compromise the vision that the Constitution of the Republic of South Africa, 1996 (hereafter the 'Constitution') sets out. ${ }^{12}$

Having entrenched the rule of law and a justiciable Bill of Rights, our Constitution sets out a vision for a transformed (continuously evolving and more) egalitarian society. ${ }^{13}$ Klare points out that our constitutional order is less liberal and more post-liberal. ${ }^{14}$ This is owing to our constitutional dispensation breaking - yet not totally from liberalism, in order to empower the state to carry out a mandate of reconstruction, revamping and remodelling (a 'transformative role and mission'). ${ }^{15}$ Klare, citing Du Plessis $v$ De Klerk, asserts that the Bill of Rights does not only impose negative restraints on the state (i.e. provide civil liberties to limit the state), but also imposes

$6 \quad R v$ Keegstra (1990) 3 SCR 697 para 227.

7 K Klare 'Legal culture and Transformative Constitutionalism' (1998) 14 South African Journal on Human Rights 146, 150.

82002 (4) SA 294 (CC) para 45.

9 Islamic Unity (n 8) para 45; Klare (n 7) 150.

10 Islamic Unity (n 8) para 45.

11 Milo et al (n 5) 76; Islamic Unity (n 8) paras 33, 45.

12 Islamic Unity (n 8) paras 33, 45.

13 Klare (n 7) 151, 156, 171; D Moseneke 'The fourth Bram Fischer memorial lecture - transformative adjudication' (2002) 18 South African Journal on Human Rights 309, 316.

14 Klare (n 7) 152. It appears that Klare is referring to the notion or principle that freedom, as a default, ranks above state interventionism or interference.

15 Klare (n 7) 153, 155 
affirmative duties on government to, inter alia, promote social welfare and assist people in enjoying their constitutional rights. ${ }^{16}$ Any state ought rightfully to be concerned with, and at least have a legitimate interest in, curtailing hate speech in the name of dignity and equality. ${ }^{17}$ None more so than South Africa, having relatively recently transitioned from a long history of institutionalised racism and inequality. ${ }^{18}$ As aforementioned, the state appears to bear a special responsibility in ameliorating harm and securing rights.

However, in recognising what the flag meant as a symbol and what it still means to those who were subjugated under its colours, one must also resist the 'knee-jerk' reaction to 'transform' and 'redress' the situation by quick panacea or through wholesale prohibition. It is important to recognise that long-term goals can be compromised by immediate or inter-mediate solutions intended to rectify historical injustice. This is why the courts, when reviewing such measures, are enjoined to enquire whether any such initiative will further the constitutional vision in the long term. ${ }^{19}$

As pointed out by Meyerson, censorship laws can easily mutate through different application or over time; the intention in drafting might be to address one character of expression, but the law can be deployed alternatively to prohibit other types of expression proven to be expedient for the government of the day. ${ }^{20}$ The obvious danger is, whilst we might accept a 'neutral' law for its good intentions in the moment, that same law might later be wielded as a weapon against what we hold dear. It is precisely because hate speech exists in such an emotionally charged orbit that it is likely to be regulated with a heavy and overly broad hand. ${ }^{21}$ This, in-and-of itself, is cause for concern in a constitutional and rights driven democracy such as South Africa. There are two primary reasons for said concern: the value of (largely) uninhibited expression in general; and more specifically, the need for a young democracy to come to terms with its new identity organically, while it is gripped in the 'teething' process of transition out of a particularly painful past (with very real vestiges still remaining). Both concerns are amplified by the protection that section 16 of the Constitution affords almost all species of expression - except for its specifically enumerated exceptions. ${ }^{22}$ As stated above, the Nelson Mandela Foundation has asked of the Equality Court

16 Du Plessis v De Klerk 1996 (5) BCLR 658 (CC) para 147. Klare (n 7) 154. Klare also references the Preamble as well as secs 1(a), 7(2) \& 39(1) of the Constitution.

17 Islamic Unity (n 8) para 33.

18 Milo et al (n 5) 73.

19 Minister of Finance and Other $v$ Van Heerden 2004 (6) SA 121 (CC) para 44. This is when considering matters of discrimination and measures purporting to be the implementation of substantive equality or redress.

20 D Meyerson "“No platform for racists": what should the view of those on the Left be?' (1990) 6 South African Journal on Human Rights 394, 397.

21 Milo et al (n 5) 73.

22 Sec $16(2)$ of the Constitution. 
to exercise its powers under section 21 of PEPUDA and place an almost outright ban on the display of the apartheid flag: a near blanket ban. ${ }^{23}$

\subsection{The inherent value of speech}

Although it has expressly disavowed the US Supreme Court's jurisprudence of First Amendment (freedom of speech) 'preeminence', the Constitutional Court has recognised the fundamental importance of the right to freedom of expression, characterising it as the 'lifeblood of an open and democratic society cherished by our Constitution' and a prime freedom 'upon which all the other freedoms depend'.24 The protection of the right to expression is widely considered intimately connected to the ideals fundamental to a constitutional and rights driven democracy.

A motivation for the entrenchment of a general right to freedom of expression is the promotion of autonomy and dignity: that everyone is rational and of equal worth, that no person should be told that their views are less valuable and should therefore not be expressed. ${ }^{25}$

Traditionally, the 'search for truth' and 'the marketplace of ideas' theories have been propositioned as champions for contesting historical and contemporary restrictions on the 'free trade' in information. 26 The logic is that a decrease in the restriction on information disseminated increases the rate of collision of different strings of information, thereby increasing the likelihood of lingering falsity being cancelled out and the truths contained in the different pieces of information being revealed and established. ${ }^{27}$ Milo, Penfold and Stein astutely conclude that these theories are especially compelling when some objectively ascertainable fact is at issue and its veracity might result in some good being achieved. ${ }^{28}$ They further note that the rationales apply equally to the contents of 'opinion', as one opinion might be more correct than another and might, by its utterance, persuade others to accept it. ${ }^{29}$ Schauer asserts that the purpose is not solely the attainment of objective truth but of 'epistemic advancement' in general. ${ }^{30}$ A case can be made for

23 SAHRC https://www.sahrc.org.za/index.php/sahrc-media/news/item/1780-bidto-ban-old-racist-sa-flag (n 4); Ryan (n5) https://www.groundup.org.za/article/ equality-court-asked-declare-old-sa-flag-hate-speech/.

24 S v Mamabolo (E TV and Others intervening) 2001 (3) SA 409 (CC) paras 40, 41; Dikoko v Mokhatla 2006 (6) SA 235 (CC) para 92; Mandela v Falati 1995 (1) SA 251 (W) para 259.

25 Milo et al (n 5) 14.

26 The justification is widely considered attributable to John Milton's articulation, dating to around 1644. See Abrams v US $250616,628,40$ SCt 17 (1919) para 637.

27 J Mils \& E Rapaport On liberty (1978) 16, 19.

28 Milo et al (n 5) 18.

29 As above.

30 As above; FF Schauer Free speech: a philosophical enquiry (1982) 18. 
opening up this 'market place' to ensure greater access for those who are impoverished or disfavoured, as opposed to further restricting it. 31

In their assessment, because government is poorly placed to do so, Milo, Penfold and Stein properly caution against government regulation of the exchange of information, except in the most considered and necessary of circumstances. ${ }^{32}$ They argue that government invariably has a stake in the information being exchanged because the information would often (or at least might) be about it or its political interests, i.e. maintaining or changing the status quo. ${ }^{33}$

Another more prominent case for speech protection is the proper functioning of democracy: that freedom of expression is the vector for the realisation of the 'twin values' of accountability and participation. ${ }^{34}$ O'Reagan $\mathrm{J}$ insightfully posited in Khumalo and Others $v$ Holomisa (hereafter Khumalo): 'without [freedom of expression], the ability of citizens to make responsible political decisions and to participate in public life would be stifled'. ${ }^{35}$ The Constitutional Court has recognised the interplay between access to information and the right to vote in no less than two landmark rulings: Democratic Alliance $v$ African National Congress and Another (hereafter ANC $\vee$ DA), and My Vote Counts NPC $v$ Minister of Justice and Correctional Services and Another (hereafter My Vote Counts). ${ }^{36}$ The premise of this argument is not that freedom of expression flows from the democratic model, but that it is a necessary precondition for it to operate effectively. ${ }^{37}$

Self-fulfilment bolsters the need to protectively ring-fence freedom of expression because it allows for the 'free development of an individual's intellect, interests, tastes and personality'. ${ }^{38}$ Van der Westhuizen $\mathrm{J}$ aptly captured the proposition in stating:

[E]xpression is an essential part of one's awareness of oneself, one's very being, and one's human dignity. There is thus an element of the

31 Milo et al (n 5) 19, 20.

32 Milo et al (n 5) 21.

33 As above.

34 Milo et al (n 5) 23.

352002 (5) SA 401 (CC) para 21; Milo et al (n 5) 24.

36 Democratic Alliance v African National Congress and Another 2015 (2) SA 232 (CC). The Court emphasised the interconnectivity between the right to freedom of expression, and that suppressing speech in an election period would inhibit valuable speech necessary to promote open and vigorous debate on public affairs primarily needed to inform the electorate and help them form their opinions. My Vote Counts NPC v Minister of Justice and Correctional Services and Another 2018 (5) SA 380 (CC).

37 Milo et al (n 5) 24.

38 Gardener $v$ Whitaker 1995 (2) SA 672 (E); see also Case and Another $v$ Minister of Safety and Security and Others; Curtis v Minister of Safety and Security and Others 1996 (3) SA 617 (CC) para 26 (Mokgoro J: freedom of expression 'is foundational to each individual's empowerment to autonomous selfdevelopment'); Milo et al (n 5) 25. 
protection of dignity involved in the protection of expression. Therefore not only true or meaningful statements, which could contribute to a debate, are protected, but also other forms of expression, simply because it is human to communicate. ${ }^{39}$

Moreover, as much as it is a human necessity for the iterator to express, it is equally important for the receiver to discern and be exposed to varying types, qualities and contents of information only receivable when speech can flow freely. ${ }^{40}$ It speaks to the development of one's identity through an appreciation and evaluation of the content.

\subsection{Free speech as a necessary ingredient in South Africa's transition}

A question of tolerance arises: Would more (especially controversial) speech result in greater tolerance? The Constitutional Court has answered this inquiry by identifying tolerance as a mere 'acceptance of the airing of disagreements' - not necessarily the 'approbation of' a point's substance - by 'refusing to silence unpopular [or offensive?] views'. ${ }^{41}$ The Court in Minister of Home Affairs v Fourie (Doctors for Life International and Others, Amici Curiae); Lesbian and Gay Equality Project and Others $v$ Minister of Home Affairs (hereafter Fourie) pronounced that, where difference in diversity is concerned, the Constitution, specifically the right to equality, rejects the 'suppression of difference' and requires an 'acknowledgment and acceptance of difference' that 'celebrates the diversity of the nation'. 42 The Court crucially stated that the test for tolerance is how one 'accommodates the expression of what is discomforting'. 43

Klare is correct in referring to the Postamble of the Interim Constitution in his motivation for our constitutional order to continue being that 'historic bridge'. ${ }^{44}$ Our young democracy is still in flux, still finding its feet. For this reason, freedom of expression is all-the-more important as it forces people to confront differences in points of view and develop a common understanding. ${ }^{45}$ This is even where disagreement on the substance exists. Of course, as observed above, it might be necessary to ban certain categories of speech that are

39 Holomisa v Khumalo 2002 (3) SA 38 (T) para 61; Milo et al (n 5) 26.

40 Milo et al (n 5) 26, 27.

41 South African National Defence Union v Minister of Defence and Another 1999 (4) SA 469 (CC) (hereafter SANDU v Minister of Defence) para 8; Milo et al (n 5) 28.

422006 (1) SA 524 (CC) para 60; Milo et al (n 5) 29.

43 Fourie (n 42) para 60; Milo et al (n 5) 29.

44 Klare (n 7) 155; Postamble of the Constitution of the Republic of South Africa Act 200 of 1993.

45 V Blasi 'Free Speech and good character' in L Bollinger \& G Stone (eds) Eternally vigilant: Free speech in the modern era (2002) 46, 84. 
inherently repugnant to, for example, our grand project of national reconciliation. 46

Withstanding the above, it must be noted that critics argue that, beyond the lack of empirical evidence to prove that hate speech bans achieve their ends, they may, as a matter of fact, be self-defeating. ${ }^{47}$ Enforcement of a prohibition brings greater attention to the cause of the offender through publicity. ${ }^{48}$ This carries the possibility of martyring them. ${ }^{49}$ Klare's work emphasises that the Constitution's blueprint is a fundamentally broad conceptualisation of society that, by design, is meant to be timeless and must continue revising the status quo. ${ }^{50}$ It should be clear then that (mostly) unbridled expression is one of the best devices for challenging the status quo. However, on this score, and as noted above, the law often becomes a weapon for silencing those disaffected and vulnerable classes of society who speak out against the status quo and who criticise the government, as was the case under apartheid. ${ }^{51}$ This 'self-defeating' thesis also extends a word of warning, that suppression must be undertaken with careful consideration. This is because 'to drive evil underground can actually increase its strength'. ${ }^{52}$ This is instead of allowing it to either 'bleed off' through a safety valve of freedom of expression, or confronting it in the open. ${ }^{53}$ Open confrontation made more probable by expressive freedoms is likely to reveal the repugnant nature of evil speech. ${ }^{54}$ Restriction and suppression on the other hand might actually cause bigotry to fester into violent eruption. ${ }^{55}$

One must consider that the expression of views, ideas, ideology or information in general falls on a spectrum, i.e. in the margins as much as it does in grey areas. First, it is often questionable whether a particular statement actually constitutes hate speech (and this answer will also depend on what the test for hate speech is at the particular time). It might be that a statement before a court is misclassified. It might be that a massive and important 'cold-war' discourse, raging as an undercurrent in society, fails to surface into

Klare (n 7) 155.

As above.

This has been seen recently in reporting of persons such as Penny Sparrow and Velaphi Khumalo: the media replicates and distributes the very incendiary content the law seeks to quash.

Milo et al (n 5) 77, 78. See Keegstra (n 6) para 304.

Klare (n 7) 155.

Milo et al ( $\mathrm{n}$ 5) 78. L Johannessen 'A Critical View of the Constitutional Hate Speech Provision' (1997) 13 South African Journal on Human Rights 135, 136. Meyerson (n 20) 397; Milo et al (n 5) 78.

Milo et al (n 5) 29.

Meyerson (n 20) 397.

As above; Milo et al (n 5) 78. 
the public arena because nobody speaks up for fear of being reported or prosecuted, or because of a recent court ruling on the subject. 56 The implication is that society then cannot grapple with systemic and institutional problems such as silent 'dog-whistle' racism or antiSemitism. ${ }^{57}$

In the instance that the expression itself carries no substantive value, nonetheless, the debate that flows from its dissemination might. It seems that there is value in discovering what hateful people think and why, so that, inter alia, misconceptions can be confronted and unacceptable ideologies combatted. The only way to undertake such investigation is - aside from probing brains - to cultivate an environment conducive to robust and expressive dialogue and having society speak up. The trade-off then is obviously allowing people to purchase and spend airtime in our various spaces of discourse, to the offense, or even hurt, of some or many.

The Constitutional Court in S v Mamabolo had the following to say about the right to freedom of expression and it bears even greater importance during this period which one can classify as 'the emergence from oppression':

Freedom of expression, especially when gauged in conjunction with its accompanying fundamental freedoms, is of the utmost importance in the kind of open and democratic society the Constitution has set as our aspirational norm. Having regard to our recent past of thought control, censorship and enforced conformity to governmental theories, freedom of expression - the free and open exchange of ideas - is no less important than it is in the United States of America. It could actually be contented with much force that the public interest in the open marketplace of ideas is all the more important to us in this country because our democracy is not yet firmly established and must feel its way. Therefore we should be particularly astute to outlaw any form of thought control, however respectably dressed. ${ }^{58}$ (emphasis added)

The Court implies that, in some part at least, progress in society will need to occur organically as the South African society finds its own truth and identity through collision with error. Such collision and

56 S Teichner 'The hate speech provisions of the Promotion of Equality and Unfair Discrimination Act 4 of 2000: the good, the bad and the ugly' (2003) 19 South African Journal on Human Rights 349, 366.

57 A 'dog whistle' is a political term for statements that appear innocent to the general public but they actually use subtle, coded language to communicate a secondary message to an intended group. Dictionary.com 'Dog whistle' https:// www.dictionary.com/e/politics/dog-whistle/ (accessed 6 August 2019). This raises the issue that implicitly racist and bigoted people often find ways of using in coded language to communicate with, for example, their supporters and political base. Lowering the threshold for a general test to target the innuendo and connotation that is situated within coded speech risks targeting important and legitimate speech that contains no such innuendo. It might possibly even chill whistle blowing or calling out and criticism of the use of the coded language in the course of robust debate. See Teichner (n 56) 366.

58 Mamabolo (n 24) paras 40, 41. 
identity mapping, as set out above, can only occur where the error is permitted to rear its head. Tolerance is of immense importance, especially when considering the need for South Africa to 'feel its way' through discourse, even if that discourse is uncomfortable.

The appeal committee of the Human Rights Commission in Freedom Front $v$ South African Human Rights Commission (hereafter Freedom Front) noted the danger of interpreting section 16(2)(c) widely in observing that:

[S]peech that is vitally important to the advancement of our constitutional democracy may be classified as hate speech, because our society is still in respect of significant social issues, divided on racial [and other fault-] lines. Any test suggested for interpreting section $16(2)$ (c) must recognise that the section is an exception and that the protection of the freedom of expression is the norm. ${ }^{59}$

\subsection{Preliminary conclusion: Proceed with caution}

In summary then, it is clear that hate speech has the capacity to cause harm, and further lacks value - indeed, racism and the like have no merit - except for the value that can be ascribed to all expression in general (its 'inherent value'). ${ }^{60}$ This inherent value might be situated in the expression's premises or its margins, or in the debate that flows from its dissemination. Patently, much 'hate speech' will be valueless in content, but that is all the more reason why it is crucial to properly calibrate the law to surgically strike only at expression that is unprotected or can be justifiably limited. It is obvious that the state has a role to play in regulating such speech. The question is how?

\section{Section 16 of the Constitution: The right to freedom of expression}

\subsection{The South African approach to freedom of expression}

Section 16 of the Constitution entrenches the right to freedom of expression. It is structured in two parts. ${ }^{61}$ Section $16(1)$ provides both a general right to freedom of expression that goes beyond its listed components, as well as a list of specifically protected forms of expression; and section 16(2) carves out certain categories of

59200311 BCLR 1283, 1297; Milo et al (n 5) 84.

60 Meyerson (n 20) 397. I most certainly align myself with this position.

61 Sec 16 of the Constitution provides that -

Everyone has the right to freedom of expression, which includes -

freedom of the press and other media;

freedom to receive or impart information or ideas;

freedom of artistic creativity; and

academic freedom and freedom of scientific research. 
expression from the constitutional protection afforded by section $16(1) .^{62}$

Section 16's scheme demands a default setting of protection for any expression that falls within its ambit. This is aptly explained by the Court in De Reuck $v$ Director of Public Prosecutions (Witwatersrand Local Division) and Others (hereafter De Reuck) where it held that even content with 'little value', in casu child pornography, fell under section 16(1)'s protection because it was not and is not a form of expression excluded by section 16(2). ${ }^{63}$

Section 16(1) protects all forms of freedom of expression not specifically excluded by section $16(2) .{ }^{64}$ Where expression falls within subsection (2), it does not enjoy the protection of the constitutional right to freedom of expression. If the expression falls within section $16(2)$, no constitutional right is impacted because it is as if, for the purposes of that expression, the right does not exist. What follows is that expression envisaged by section 16(2) is always trumped by a limiting law because it has no constitutional protection to raise as a shield. ${ }^{65}$

It is of importance to note that section 16(2) does not prohibit any form of expression itself. ${ }^{66}$ It only removes constitutional protection from the species of expression it enumerates. ${ }^{67}$ This means that any limitation of any expression that is not contemplated by section 16(2) must satisfy section 36(1) limitation - because it is automatically afforded the protection of the right. ${ }^{68}$

Even within the parameters of section 16(1), freedom of expression is not an absolute right, but can be limited by a law of general application in terms of section $36(1) .{ }^{69}$ It is also not a 'paramount value'. 70 Our courts have expressly disavowed the US

The right in subsection (1) does not extend to -

propaganda for war;

incitement of imminent violence; or

advocacy of hatred that is based on race, ethnicity, gender or religion, and that constitutes incitement to cause harm.

62 Islamic Unity (n 8) paras 31-33.

632004 (1) SA 406 (CC) para 61.

64 Milo et al (n 5) 11.

65 As above.

66 Islamic Unity (n 8) para 32; 'Supreme Court of Appeal gets the law very wrong in a Hate Speech judgment' $P$ de Vos 6 December 2018 https://constitutionallys peaking.co.za/supreme-court-of-appeal-gets-the-law-very-wrong-in-a-hate-spee ch-judgment/ (accessed 18 May 2019) (De Vos 2018); 'Qwelane: Still a homophobe, but his challenge to hate speech clause is sound' $P$ de Vos 3 September 2013 https://constitutionallyspeaking.co.za/qwelane-still-a-homo phobe-but-his-challenge-to-hate-speech-clause-is-sound/ (accessed 18 May 2019) (De Vos 2013).

67 Islamic Unity (n 8) paras 31-33.

68 Milo et al (n 5) 6; Islamic Unity (n 8) paras 31-33.

69 Phillips V DPP, Witwatersrand Local Division 2003 (3) SA 345 (CC) (hereafter Philips) para 17.

70 Khumalo (n 35) para 25. 
Supreme Court's jurisprudence of the First Amendment (freedom of speech) 'pre-eminence'. ${ }^{71}$ Instead, the Courts have opted for a balancing of rights based on the facts of each case when determining the validity of a limitation or contest between two competing rights. ${ }^{72}$ This means that the freedom of expression, as important as it is, does not automatically 'trump' a right such as human dignity. ${ }^{73}$

The courts have broadly interpreted 'expression' as contained in section 16 as including 'any material that communicates or attempts to communicate meaning'. ${ }^{74}$ This would obviously include any attempt to communicate verbally, to publish, to write and to display content or information. The right to freedom of expression supplied by section 16 extends to and protects even offensive, shocking, and disturbing content. ${ }^{75}$ As it should for the conceptual reasons laid out above. $^{76}$

\subsection{The exclusions: Section 16(2)}

The pivotal inquiry therefore is whether the mere display of the flag amounts to 'advocacy of hatred that is based on race, ethnicity, gender or religion, and that constitutes incitement to cause harm'. ${ }^{\prime}$ If it does amount to such expression, then the enquiry and indeed this article would end here. The flag would not be protected by the right to freedom of expression. Legislation, namely PEPUDA, would be able to prohibit it (by classifying it as hate speech) without any need for section 36(1) justification. There would be no grounds for the balancing of rights and no attendant discussion. If it does not constitute excluded expression, then PEPUDA's prohibition will constitute an infringement of the right because the display will be protected under section 16(1).

Section 16(2) enumerates three types of expression that are ousted from constitutional protection. ${ }^{78}$ The list includes propaganda for war and expression amounting to advocacy of hatred that incites harm. The exclusion with the lowest threshold relevant to PEPUDA's section 10 hate speech prohibition, as well as the display of the 'old South African flag', is section 16(2)(c), which in two elements, allows for the limitation of 'egregious hate speech'. 79

71 Mamabolo (n 24) paras 40, 41

72 Mamabolo (n 24) paras 41.

73 As above.

74 Milo et al (n 5) 10; De Reuck (n 62) para 48.

75 Islamic Unity (n 8) para 28; De Reuck (n 62) para 49.

76 See paragraph 2.2 and 2.3 of this article.

77 Sec $16(2)$ of the Constitution.

78 As above.

79 Milo et al (n 5) 11. 
For expression to amount to 'egregious hate speech' as contemplated by section 16(2)(c), it must: (i) amount to advocacy; (ii) qualify as hatred; (iii) be based on race, ethnicity, gender or religion; (iv) constitute incitement; and (v) be directed to causing harm. If not, the requirement of section $36(1)$ justification is triggered to serve as the limitation.

Section $16(2)(c)$ sets a compounded and high threshold. ${ }^{80}$ The advocacy of hatred (a high internal threshold) will, by itself, be insufficient to trigger the ousting of the right to freedom of expression. ${ }^{81}$ The contentious issues are dealt with in turn below.

\section{(i)}

\section{'Advocacy'}

'Advocacy' implies the active promotion of a cause. ${ }^{82}$ Currie and de Waal classify advocacy as, to 'call for or make a case for' the cause. ${ }^{83}$ 'Advocate' is a strong verb. ${ }^{84}$ It has been described as 'exhortation, pleading for, supporting or coercion'. ${ }^{55}$ The Canadian Supreme Court in $R \vee$ Keegstra described 'advocacy' in the following language, stating:

['Promotes hatred'] indicates active support or instigation ... [it] indicates more than simple encouragement or advancement. The hatemonger must intend or foresee as substantially certain a direct and active stimulation of hatred against an identifiable group. ${ }^{86}$

Klare admits that, whilst exegesis must be through a transformative matrix, the law is not infinitely plastic. ${ }^{87}$ It is difficult to conceive how displaying the flag in isolation can constitute active conduct that is, anything more than passive encouragement or support - let alone exhortation or coercion. Furthermore, the terms 'advocacy', 'hatred' and 'incitement', individually but more so cumulatively, indicate that the constitution requires subjective intention on the part of the person making the expression. ${ }^{88}$ At most, displaying the flag could (discretely) be considered passive yet open or public support for the apartheid regime or any of its aspects; or it could be a component of some larger scheme of conduct which might, cumulatively, constitute advocacy. However, in-and-of itself, the flag, even as a powerful symbol, does not meet the high threshold.

80 Milo et al (n 5) 79.

81 As above.

82 Milo et al (n 5) 80.

83 I Currie \& J de Waal The Bill of Rights Handbook (2005) (5th ed) 375.

84 J Botha \& A Govindjee 'Hate speech provisions and provisos: a response to Marais and Pretorius and proposals for reform' (2017) 20 Potchefstroom Electronic Law Journal/Potchefstroomse Elektroniese Regsblad 1, 13.

85 C van Wyk 'The Constitutional treatment of Hate Speech in South Africa' (2003) 18 SA Publiekreg /SA Public Law 182185.

86 Keegstra (n 6) para 120.

87 Klare (n 7) 149.

88 Milo et al (n 5) 83. Teichner (n 56) 380. 
There are two contexts which are important here. First is the historical context of racial injustice that the symbol of the flag might propound in consequence. Its symbolism must inflict a profound hurt that has been imposed on the majority of the South African population for centuries. However, this context must be considered in light of section 16(2)(c) which requires a certain quality and intensity of the content. The standard is not 'to merely offend or upset' (which, as noted above, is protected); a higher threshold of 'hatred' is set. This is clear from the holding in $R \vee$ Andrews, where the Canadian Supreme Court stated that hatred cannot be 'casual' (possibly, to also mean inadvertent, unintentional or normal), but it connotes the 'instilling of malevolence'. ${ }^{89}$

Modiri contributes to the definition of 'white supremacy' (which a transformative constitution obviously turns its back on) by, in part, stating that it includes:

... (3) relations and images of white dominance and Black subordination [that] are re-enacted daily across a wide array of institutions, spaces, platforms, media and social settings - both private and public, intersubjective and structural. ${ }^{90}$

The flag might well be such a re-enactment in certain contexts. As contextualised above, hatred is an extreme emotional standard. The flag has a range of calibrations, which are set according to context (in terms of conduct or words). In some contexts, the flag might be an element in an artistic or journalistic creation; in others, it might be a rallying cry. Flying the flag coupled with some other qualifying conduct would probably add up to hatred. If displaying the flag was intended to romanticise and reminisce on the days of apartheid, it could rise to the standard of spreading hatred owing to its status as a symbol of deep division and dehumanisation when taken in the context of apartheid.

Withstanding the above, 'hatred' seems to imply an element of subjective intention; that the emotion wrought behind the content must be directed and purposeful, or at least conscious. This conclusion aligns with some of the commentators who analysed the elements of 'advocacy' and 'hatred' conjunctively. ${ }^{91}$ The purpose of the advocacy is to spread the hatred. The hatred serves to demonise and invite harm upon the targeted group or its members. If subjective intention is an internal element of 'hatred', then an objective

$89 R \vee$ Andrews (1990) 3 SCR. 870 para 211.

$90 \mathrm{~J}$ Modiri 'The "Event" of racism' 17 November 2016 https://www.daily maverick.co.za/opinionista/2016-11-17-the-event-of-racism/\#.WJI4BvKf1Hw (accessed 14 May 2019).

91 Milo et al (n 5) 80; Teichner (n 56) 380. 
inference in-and-of itself will be insufficient to discharge the burden of proving 'hatefulness' in respect of flying the flag.

Section $16(2)$ (c) requires 'advocacy of hatred' as a means to a specific end, namely, causing harm. As aforementioned, hate speech has the potential to do 'emotional damage' thereby, occasioning 'grave psychological and social' harm in the form of humiliation and degradation. 92

It is accepted that 'harm' is not limited to the realm of the physical but extends to psychological and other forms of harm that can be perpetrated. However, as the appeal committee of the South African Human Rights Committee held, the harm must be significant and surpass mere offence. ${ }^{93}$ The harm must be something material coupled with another injury such as violence, harassment or verbal abuse. ${ }^{94}$

The Constitutional turning point, however, is indirect causation. It is not whether the speech itself did the harming but whether it would incite others to cause harm. ${ }^{95}$ Again, as with 'advocacy', incitement requires that the utterer act towards the objective of generating some material outcome by way of their expression. As Milo, Penfold and Stein explain, the harm must flow from the hate speech. ${ }^{96}$ They correctly argue that the speech must 'amount to advocacy of hatred and [as well as] incitement to cause harm', and that hatred or advocacy of hatred, without incitement to cause harm, is insufficient to trigger section $16(2)(c) .{ }^{97}$

Section 16(2)(c) encompasses, for example, an inflammatory speech at a local meeting calling for the lynching of black neighbours, or the propositioning at that meeting to phone and harass black neighbors with the object of driving them out of town. ${ }^{98}$ It does not seem as though the old flag can do any of this by itself, unless it is a pre-arranged signal for a pact to be implemented. But even then, any flag could be a pre-determined and specified indicator - the current South African flag could even be used for such a purpose.

92 Keegstra (n 6) para 227.

93 Freedom Front (n 59) 1295.

94 Milo et al (n 5) 83.

95 As above.

96 Milo et al (n 5) 79.

97 As above.

98 As above. 


\subsection{Constitutional status of the flag}

It is therefore clear that the flag, whilst understandably hurtful and hateful to many, cannot fall into the exclusions. It thus finds its way into the penumbra of section 16(1) and therefore constitutes protected expression by default. The question is then whether the protected right can be limited in the way that section 10 of PEPUDA does.

\section{Constitutionality of section 10 of PEPUDA}

\subsection{Inconsistency with Section 16(2)}

As set out above, the Constitution carves out 'hate speech' from its protection as a species of expression and in doing so establishes a high threshold. Section 10 of PEPUDA lowers that watermark substantially and implicates - and thereby civilly limits - speech on a far more drastic basis. ${ }^{99}$

There are several discrepancies between section $16(2)(\mathrm{c})$ and section 10 of PEPUDA. For example, section 16(2)(c) of the Constitution only requires that the speech in question incite some sort of harm (that the harm is one step removed from the speech). However, section 10 of PEPUDA ensnares speech which does the harming or hurting itself. ${ }^{100}$ Section 10 also increases the number of grounds from the four listed in section 16(2)(c), on which hate speech can be perpetrated, to sixteen. ${ }^{101}$

Both inconsistencies are arguably permissible and justifiable limitations of the right to freedom of expression. First, the additional grounds merely bring the list at section 16 more closely in line with section $9(3)$ of the Constitution. ${ }^{102}$ Second, tackling direct (as opposed to only indirect) adverse consequences of incendiary speech is consonant with our constitutional jurisprudence which recognises the state's interest in preventing all or any harm, and that harm can flow directly from hateful speech. ${ }^{103}$

99 Milo et al (n 5) 86; See secs 21 of PEPUDA for a list of the powers and functions of the Equality Court which may be invoked in matters of hate speech; the list appears to include prohibition. See de Vos 2013 (n 67) https://constitutionally speaking.co.za/qwelane-still-a-homophobe-but-his-challenge-to-hate-speechclause-is-sound $/$.

100 Milo et al (n 5) 88.

101 See sec 1 of PEPUDA ('Prohibited grounds').

102 L Botha \& A Kok 'How to make sense of the civil prohibition of Hate Speech in terms of the Promotion of Equality and Prevention of Unfair Discrimination Act 4 of 2000' to be published in Southern Africa Public Law (draft on file with author) 20.

103 Islamic Unity (n 8) paras 33 \& 45. 
The two main problems with section 10 are the lowering of thresholds, and the imposition of an objective, reasonable person test that ignores subjective intention.

\section{(i)}

\section{Hurtfulness}

The threshold of section 10 is lowered by employment of the standard of 'hurtful[ness]'. Section 10 of PEPUDA stipulates that a person may not 'publish, propagate, advocate or communicate words' that 'could reasonably be construed to demonstrate a clear intention to be hurtful; harmful or incite harm; or promote or propagate hatred'.

'Harmful' and 'hatred' are textually consistent with section $16(2)$ (c) and so there is likely no constitutional challenge to be made on that score. However, the word 'hurtful' (read with 'harmful') casts a much broader net. ${ }^{104}$ This is especially true when interpreted against the reasonable person standard. ${ }^{105}$ The hate speech prohibition could then target an inordinate portion of discourse which society actually considers acceptable, if not beneficial, ranging from insensitive jokes made privately to robust opinions on racial issues. ${ }^{106}$ De Vos illustrates this point well by arguing that any genuine view on a specific issue that implicates a listed ground can likely be taken, objectively, as offensive and hurtful. ${ }^{107} \mathrm{He}$ asserts that this would include religious teachings on subjects such as homosexuality, with the unacceptable result of such religious expressions being prohibited or sanctioned. 108

Several examples highlighted by De Vos are religious in nature. In the most extreme exercise of the Equality Court's powers, the banning of the communication of religious teachings will strike at rights such as one's section 15 right to freedom of religion, thought, conscience and belief, as well as the right to form cultural and religious communities (section 31 of the Constitution). Religious and

104 De Vos 2013 (n 66) https://constitutionallyspeaking.co.za/qwelane-still-ahomophobe-but-his-challenge-to-hate-speech-clause-is-sound/; Milo et al (n 6) 87.

$105 \mathrm{~J}$ Modiri 'Race, realism and critique: the politics of race and Afriforum $v$ Malema in the (in)equality court' (2013) 130 The South African Law Journal 274; De Vos 2013 (n 66) https://constitutionallyspeaking.co.za/qwelane-still-a-homophobebut-his-challenge-to-hate-speech-clause-is-sound/.

106 Milo et al (n 5) 87.

107 De Vos 2013 (n 66) https://constitutionallyspeaking.co.za/qwelane-still-ahomophobe-but-his-challenge-to-hate-speech-clause-is-sound/ ("Much of the teaching of mainstream religious groups on homosexuality, for example, would almost certainly fall foul of the hate speech provision. When a priest or imam targets "practicing" gay men and lesbians (as if we need any practice) in a talk and brands us as "sinners", many so called reasonable people will surely assume that they had the intention to be hurtful to gay men and lesbians ... But should such speech be banned? I am far from certain that it should').

$108 \mathrm{Or}$ at least deterred by apprehension or by the sanctions imposed by the court. See De Vos 2013 (n 66) https://constitutionallyspeaking.co.za/qwelane-still-ahomophobe-but-his-challenge-to-hate-speech-clause-is-sound/. 
cultural groups would be inhibited from imparting doctrines, cultural understandings and teaching practices. Such abilities form the foundation of these associations and aspects of life. ${ }^{109}$

Milo, Penfold and Stein suggest an interpretative prophylactic: that 'harm' can be interpreted narrowly to only physical harm or violence; and 'hurtful' restrictively to extend to only serious and material consequences, in line with the constitutional standard analysed above. 10

Botha and Kok take up the gauntlet in opposition to this, countering that the impugned standard of 'hurtfulness' was in fact vindicated (in delictual terms) by the Constitutional Court in Le Roux and Others $v$ Dey (hereafter Le Roux $v$ Dey) - read with its holding in The Citizen 1978 (Pty) Ltd v Mcbride (hereafter Citizen v Mcbride). ${ }^{111}$ They effectively argue that the holdings in these cases render the standard a constitutionally permissible ingredient in any the limitation of freedom of expression. ${ }^{112}$ They submit that because the standard is good in delict, it is good in PEPUDA. ${ }^{113}$

I am not certain that I can countenance this proposition. First, fault in the form of actual (subjective) intention is not a requirement under PEPUDA. ${ }^{114}$ It is a requirement in defamation and impairment of dignity actions which were considered by the Court in Le Roux $v$ Dey. ${ }^{115}$ Second, in defamation or impairment of dignity claims, actual hurt or harm must be effected. ${ }^{116}$ Under PEPUDA, the requirements of both causation and injury are absent. There is no requirement that harm (or hurt) actually be caused; only that the intention to do so be objectively determinable. ${ }^{117}$ These added elements in delict appear to differentiate delictual claims from those under PEPUDA.

109 S Woolman 'On the fragility of associational life: A constitutive liberal's response to Patrick Lenta' in S Woolman and D Bilchitz Is This Seat Taken? Conversations at the Bar, the Bench and the Academy about the South African Constitution (2012) 118, 119.

110 Milo et al (n 5) 87. See paragraph 3.2 of this article.

1112011 (3) SA 274 (CC) para 119; 2011 (4) SA 191 (CC) para 79; Botha \& Kok (n 102) 25.

112 Botha \& Kok (n 102) 25; Le Roux v Dey (n 111) para 119; Citizen v Mcbride (n 111) para 79.

113 Botha \& Kok (n 102) 27, 28

114 Botha \& Govindjee (n 84) 14; Botha \& Kok (n 102) 21, 23 \& 24; De Vos 2013 (n 66) https://constitutionallyspeaking.co.za/qwelane-still-a-homophobe-but-hischallenge-to-hate-speech-clause-is-sound/.

115 Le Roux $v$ Dey (n 111) paras 84 \& 129-134.

116 In the form of defamatory effect or injury to dignity. Le Roux $v$ Dey (n 111) paras $84,92,118,145$.

117 Teichner (n 56) 354; De Vos 2013 (n 66) https://constitutionallyspeaking.co.za/ qwelane-still-a-homophobe-but-his-challenge-to-hate-speech-clause-is-sound/. 
Thirdly, the Court in Le Roux $v$ Dey might have approved of the 'hurtfulness' standard in the context of delict, however, as noted, the Court has twice over affirmed that offensive, shocking and disturbing content is protected. ${ }^{118}$ One of those cases is the only hate speech case that has reached the Constitutional Court. ${ }^{119}$ As far as the two precedents (arising out of different contexts) confront one another, it might not be as 'cut-and-dry'.

I therefore submit that it should not be contented outright that the Court in Le Roux $v$ Dey affirmed a universal standard of 'hurtfulness' that can be transplanted from delict into a different species of action under PEPUDA. It is my respectful submission that the Court affirmed the 'hurtfulness' standard as a part of the delictual matrix - as merely a part of the set of delictual requirements which operate in aggregate.

\section{(ii)}

\section{Objectiveness}

As noted above, the Constitution requires subjective intent through using the terms 'advocacy', 'hatred' and 'incitement'. 120 PEPUDA's breaks with that constitutional framework. It treats subjective (actual) intent as irrelevant. ${ }^{121}$

Modiri points out how Lamont J implicitly adopted a 'white' standard in surveying the facts. ${ }^{122}$ In doing so, Modiri is effectively making the legal realism and critical race theory case against the reasonable person standard because it is, through those lenses, inherently infected by indeterminacy or conscious and subconscious biases. In a similar vein, Milo, Penfold and Stein contend that formulation of section 10's intention test is vague. ${ }^{123}$

De Vos, too, criticises the standard, especially its employment by Lamont J in Afriforum v Malema (hereafter Malema). ${ }^{124}$ De Vos levels criticism against the judgment because of how it invites a judge to formulate and apply the standard of reasonableness in a seemingly impossible way - in complex matters which involve the assessment of 'hurt' on an objective, class-wide scale. Yet 'hurt' is inherently subjective. The 'purpose of hate speech regulation is to remedy the harm that it causes, whether to a target group or to the broader societal well-being'. 125

118 Islamic Unity (n 8) para 28; De Reuck (n 63) para 49.

119 Islamic Unity (n 8).

120 See paragraph 3.2 in this article. Teichner (n 56) 380; Milo et al (n 5) 83.

121 Milo et al (n 5) 87. Botha \& Kok (n 102) 25.

122 Modiri (n 106) 280-282.

123 Milo et al (n 5) 87.

1242011 (6) SA 240 (EqC); De Vos 2013 (n 66) https://constitutionallyspeaking.co.za/ qwelane-still-a-homophobe-but-his-challenge-to-hate-speech-clause-is-sound/.

125 Botha \& Govindjee (n 84) 13. Milo et al (n 5) 80, 81. 
At least in comparison to delictual actions the two leg test for hurtfulness is not to somehow legally aggregate and apply the subjective feelings of the class of persons. ${ }^{126}$ Instead it appears that the secondary objective test is to double-check and ensure that the initial subjective and individualised test fairly and reasonably gauges the hurtfulness. The secondary objective test is informed by various extrinsic contextual factors, i.e. constitutional values. ${ }^{127}$ The two leg test incorporating the reasonable person test in delict therefore makes sense. Under PEPUDA there is a single reasonable person test.

Botha and Govindjee note that hate speech regulation is purposed with remedying the effects of such speech and the harm that it causes, whether to a target group or to the broader societal wellbeing. ${ }^{128}$ Precisely because of the collective nature of the prohibited grounds on which our hate speech law is premised, the subjective nature of hurt must be abstracted from an individual circumstance and be tested on a 'behalf-of' basis'. Unlike in defamation cases relating to hurt, in hate speech the question becomes, 'What will hurt this person as a member of the group?'. This further begs the question: How does one accurately assess what is representative of the beliefs and sensitivities of an entire (and probably internally diverse) group of persons when one is not likely to be a member of the group? ${ }^{129}$ The consequence is a vague and indeterminate standard. De Vos pointedly illustrates the problem:

This means that religious and sexual minorities, say, might be entitled to special protection in terms of this Act and that a court should take note of the sensibilities of such groups when they judge whether a reasonable homosexual or a reasonable Muslim would have viewed a specific communication as having the intention to be hurtful to them.... Almost any cartoon that depicts the prophet Mohammed, say, might therefore constitute hate speech. Statements by a pastor that homosexuals are perverts that will burn in hell would also, most probably, constitute hate speech ... 130

A test of this nature makes sense when confronted with an obvious example of hurtful and hateful speech. Take the use of the ' $\mathrm{K}$-word'. It would be difficult, if not impossible, to defend its use outside of a bona fide artistic, theatrical or journalistic context. It is objectively hurtful and hateful, irrespective of what the utterer intends. Where

126 This is in respect of the claims of defamation and impairment of dignity. See Botha \& Kok (n 102) 27.

127 Le Roux $v$ Dey (n 111) para 179.

128 Botha \& Govindjee (n 84) 13.

129 And even where one is a member of the group, where the group is internally diverse, how is it possible for such a 'representative' to judge the matter on the behalf of the group's differing pluralities?

130 'Malema judgement: a re-think on Hate Speech needed' $P$ de Vos 12 September 2011 https://constitutionallyspeaking.co.za/malema-judgment-a-re-think-onhate-speech-needed/ (accessed 18 May 2019) (De Vos 2011). 
the utterer somehow has a benign intention, they must or ought to know the impact of the use of the ' $\mathrm{K}$-word'.

However, the section 10 test is not as 'clear-cut' when applied to all variances of expression, which might or might not be hurtful or construed as hateful. De Vos illustrates this by way of the example of genuine religious teachings, which may, in actuality, result in hurt but should not be prohibited merely because the reasonable person determines that the teacher could foresee the hurt arising nevertheless, continued expressing the content. ${ }^{131}$ Just because hurt is or might be occasioned does not mean, in employing the "clear intention test', that intention can be reasonably clear from the expression. Generally, the intention of the artist in sketching the cartoon or the Imam in preaching, save an indication to the contrary, is not to be hurtful, but could be for some other arguably legitimate purpose. ${ }^{132}$

As pointed out by Botha and Kok, the comparable common law actions relating to injury require, either the fault in the form of direct intention or dolus eventualis to be successful. ${ }^{133}$ These requirements have already been held to be constitutional in that they form part of a delictual matrix that straddles the fine line in protecting dignity without 'unjustifiably infringing the right to dignity'. ${ }^{134}$ In this case the comparison is apt. As Botha and Kok set out, the pure objective test in our current hate speech law sets the bar too low and occasions infringement too intense to be justified. ${ }^{135}$ Incorporating the fault requirement of intention into section 10 will raise the bar and might be a means of saving it in constitutional review.

\subsection{Reasonable and justified? Section 36(1) limitation...}

The Court appears to have set out an approach to the limitation of section 16 which grades the importance and 'protectability' of expression based on a scale of proximity to the core values of the right and our constitutional democracy. ${ }^{136}$ Expression in South Africa is therefore not measured by utility. It is important that the core is anchored in the text and values of the Constitution as opposed to being open-ended and determined by reference to a dominant class-

131 De Vos 2013 (n 66) https://constitutionallyspeaking.co.za/qwelane-still-ahomophobe-but-his-challenge-to-hate-speech-clause-is-sound/.

132 As above.

133 Botha \& Kok (n 102) 22.

134 Botha \& Kok (n 102) 25.

135 As above.

136 De Reuck (n 63) para 59. 
or prevailing cultural values, positions of morality or the prevailing wind of popular opinion. ${ }^{137}$

The limitation inquiry involves weighing the nature of the right against extent, purpose and means of the limitation in a proportionality assessment that considers all relevant factors. ${ }^{138}$ State interference is justified under transformative constitutionalism in order to secure the enjoyment of rights, especially by the vulnerable and historically oppressed. ${ }^{139}$ The purposes of the limitation by section 10 of PEPUDA are namely, the protection and advancement of equality and dignity, two fundamental rights.

As noted above, it is questionable whether there is a rational connection between the prohibition and its purpose. ${ }^{140}$ It may be possible that such suppression of speech in fact defeats the very purpose of section 10 in that it overregulates speech - and could cause a groundswell of defiant or subversive speech-activism. ${ }^{141}$

Furthermore, weighed against the purposes and means employed is the fact that freedom of expression has an increased importance (even invective speech) in a 'teething' democracy. This speaks to the extent and importance of the limitation on the right, especially where the right is of immense and momentous import.

In light of the above, it is doubtful that the limitations placed on the freedom of expression would or ought to survive constitutional scrutiny because they are overly broad and fail to sift good speech from bad (hate) speech. ${ }^{143}$

\section{Does the flag fit?}

Plainly, if section 10 were to be found unconstitutional, its formula would likely be adjusted to render it constitutional, through either judicial intervention or legislative action. ${ }^{144}$ However, inasmuch as

137 Moseneke (n 13) 315; See West Virginia State Board of Education v Barnette 538 US 343 (1943) (Justice Jackson held: 'The very purpose of a Bill of Rights was to withdraw certain subjects from the vicissitudes of political controversy, to place them beyond the reach of majorities and officials ...').

138 S v Makwanyane 1995 (3) SA 391 (CC) para 104; S v Manamela and Another (Director-General of Justice Intervening) 2000 (3) SA 1 (CC) para 33.

139 Klare (n 7) 154, 161-164.

140 Botha \& Govindjee (n 84) 27.

141 See paragraph 2.3 of this article. As is, in my own assessment occurring in US at present; not in response to legislative intervention, but in response to social movements (i.e. 'PC' or political correctness culture) and societal backlash. This 'organic regulation' has caused some quarters to feel threatened and is arguably one of the reasons that certain persons have been elected to high office.

142 See sec 36(1)(b) and (c).

143 Philips (n 69) para 28; Virginia v Black 538 US 343 (2003).

144 Judicial intervention following a finding of unconstitutionality might, for example, take the form of a reading-in or severance of words. 
that it is the existing legal regime, it is worth applying to the display of the old flag. ${ }^{145}$

The first stumbling block in applying section 10 to the flag is that the language of the statute is limited to 'publishing, propagating, advocating or communicating words'. A flag is clearly not comprised of words. 'Words' appears to be a bright and unequivocal palisade qualification to a case concerning 'speech' that is not 'speech'. Botha and Kok go as far as stating that other non-verbal forms of communication cannot fall within the ambit of section 10's hate speech provision. ${ }^{146}$

However, it is conceivable that a purposive and contextual interpretation could clear this hurdle. ${ }^{147}$ The argument is that the provision should not be frustrated by one restrictive word at odds with its intention and the intentions of the Act itself and should therefore be overlooked where the purpose demands. ${ }^{148}$ For the remainder of my assessment, I will assume that the qualification of 'words' does not present an insurmountable obstacle, so as to fully engage with the substance of this matter further.

The examination then turns to whether the flag, by its mere display, can bear an objectively inferred intention to cause hurt.

What seems to be required, for the spreading of hatred, or being hurtful, is the conveyance of sentiment to others, implying some sort of public display as regards the flag. This is because hatred is such an extreme emotional standard and because the flag has a range of calibrations, which are set according to context (conduct or words). For example, displaying the flag in private appears unlikely to amount to spreading hatred. Displaying the flag to others would likely amount to spreading hatred. ${ }^{149}$

If section 10's intention test can accommodate intention in the form of dolus eventualis, or intention of a comparable nature, then PEPUDA's objective test will likely be satisfied. ${ }^{150}$ Intention in the form of dolus eventualis requires the displayer to raise the flag having foreseen and reconciled themselves with the hurtful consequences that eventuate. ${ }^{151}$ If it can be shown that the reasonable person would realise, or is conscious of, the actual hurtful impact of the flag

145 It is also the existing enactment which is before Mojapelo DJP in South Gauteng High Court.

146 Botha \& Kok (n 102) 13, 14.

147 M Marais \& J Pretorius 'A contextual analysis of the hate speech provisions of the Equality Act' (2005) 18 PER 901, 906.

148 Marais \& Pretorius (n 147) 907.

149 Botha \& Kok (n 102) 12.

150 Botha and Kok address this matter and ultimately conclude that the section should be amended. See Botha \& Kok (n 103) 20, 25.

151 Botha \& Kok (n 102) 20, 25; Black v Joffe 2007 (3) SA 171 (C) para 39; S v Makgatho 2013 (2) SACR 13 (SCA) para 9. 
and what it represents, then they will be answerable for hate speech, even when they only harbour some benign intention. What would place displaying the flag as hate speech beyond doubt is where it is coupled with other words or conduct which relate to the symbolism of the flag and which indicate a hateful purpose in its display.

However, if the 'clear intention test' does not accommodate this form of intention in light of section 16 and its own formulation, and unless certain factors in the specific context of the case indicate positive intention, it is unlikely a clear objective intention can be inferred.

I submit that it is likely that the flag's inherent hurtfulness, in terms of section 10 of PEPUDA, warrants a court finding its display to be hate speech where it is displayed in public (or to others who would suffer hurt) outside of the ambit of section 12 of PEPUDA.

Such findings, notwithstanding the above, need to be on a caseby-case basis. The order sought by the Nelson Mandela Foundation relies precisely on the fault-lines of section 10 . The Foundation prays for a blanket classification of the gratuitous display of the flag as hate (and prohibited) speech. ${ }^{152}$ Such a classification would constitute prior restraint.

The Constitutional Court recognised the inherent danger of expression classification and censorship by prior restraint, in the context of the publication of illicit material, finding the legislation permitting such censorship unconstitutional. ${ }^{153}$ Although in Print Media South Africa and Another $v$ Minister of Home Affairs and Another (hereafter Print Media) the Constitutional Court was concerned with a provision allowing an administrative body to, before publication, review specific draft publications and therefore to censor specific publications, the Court noted that '[where an] administrative body is mandated and incentivised to classify, [it] also increases the likelihood of [prior] restraint'. 154

The implications are that were a court to declare any 'gratuitous display' of the flag as hate speech, the court would have classified the flag in a certain way (almost) regardless of the circumstances of other future cases. This would amount to a prior restraint through classification by curial edict and would supplant careful and considered analysis of the specific case of flag display. ${ }^{155}$

152 SAHRC https://www.sahrc.org.za/index.php/sahrc-media/news/item/1780-bidto-ban-old-racist-sa-flag (n 5); Ryan (n 5) https://www.groundup.org.za/article/ equality-court-asked-declare-old-sa-flag-hate-speech/.

153 Print Media South Africa and Another $v$ Minister of Home Affairs and Another 2012 (6) SA 443 (CC).

154 Print Media (n 153) para 59.

155 Print Media (n 153) para 66. 
Even if, on the specific facts of the case, the Foundation is granted the relief they sought, the Court should not hand down a broad prohibitory order, nor should it a definitive and absolute classification, for the reasons I set out above.

\section{Conclusion}

Hateful speech causes harm to intended targets and members of society alike. It erodes the fundamental values of our society in exposing our vulnerabilities to the elements of hate, violence and discrimination. Obviously the state is mandated to not only regulate but also prohibit expression that polarises and divides our society. However, it must do so in a manner that promotes the spirit, purport and object of our Bill of Rights and is reasonable and justifiable.

Specifically, the flag itself could be banned by law, but Parliament must pass such legislation, satisfy section 36(1) and supply certainty and stability therein. The role of the courts then, in furthering the transformative agenda of our Constitution, is to hold steadfast in balancing interests, testing for just outcomes and applying the law to further our constitutional ambitions.

As it stands, the flag may well constitute hate speech under PEPUDA. Whether this is a constitutionally permissible finding, in light of PEPUDA's probable constitutional flaws, is where the true debate must be located.

It is contended that it is open to Parliament to regulate hate speech in general but it must do so by sound constitutional means and not through a vague framework. It must not be heavy handed. It must be wary of not jeopardising the organic interaction and identity mapping in reaching transformative objectives that is crucial to our young democracy. 